\title{
HUBUNGAN SINTAKS BELAJAR POLYA DENGAN HIGH ORDER THINKING SKILL PADA PEMBELAJARAN MATEMATIKA SEKOLAH DASAR
}

\author{
1Farah Farri Santhi, ${ }^{2}$ Rintis Rizkia Pangestika \\ 1farahfarri09@gmail.com, 2rintisrizkia@gmail.com \\ 1,2Universitas Muhammadiyah Purworejo
}

\begin{abstract}
ABSTRAK
Penelitian ini mempunyai tujuan antara lain untuk (1) mendeskripsikan bagaimana hubungan sintaks belajar Polya dengan aspek HOTS, (2) mendeskripsikan bagaimana hubungan sintaks belajar Polya dengan domain HOTS, serta (3) mendeskripsikan bagaimana karakteristik pembelajaran matematika di jenjang Sekolah Dasar. Penelitian ini berjenis deskriptif kualitatif. Metode yang digunakan dalam kajian ini adalah studi literatur dengan memperhatikan makna. Hasil kajian menunjukkan indikator sintaks belajar Polya melahirkan tujuan dari pembelajaran problem solving. Temuan lain menunjukan bahwa indikator sintaks belajar Polya melahirkan setiap domain kognitif pada HOTS. Pencapaian HOTS di jenjang Sekolah Dasar khususnya pada proses pembelajaran matematika dilakukan dengan susunan perencanaan ide, susunan perencanaan yang dimaksud adalah sintaks belajar Polya. Salah satu aspek dari HOTS adalah problem solving. Mata pelajaran matematika di sekolah dasar menuntut peserta didik guna memiliki keterampilan pemecahan masalah. Berdasarkan hasil kajian, Polya dapat mempermudah pendidik untuk mengetahui tingkatan level ranah kognitif peserta didik, khususnya pada mata pelajaran matematika Sekolah Dasar.
\end{abstract}

Kata kunci: Polya, HOTS, matematika

\section{THE RELATIONSHIP BETWEEN POLYA'S LEARNING SYNTAX AND HIGH ORDER THINKING SKILL ON ELEMENTARY SCHOOL MATHEMATICS LEARNING}

\begin{abstract}
This research has objectives, that is (1) describe how the Polya's learning syntax relates to HOTS aspect, (2) describe how the Polya's learning syntax relates to HOTS domain, and (3) describe how the characteristics of mathematics learning at the elementary level. This research is a descriptive qualitative type. The method used is literature study by paying attention to meaning. The result of the study show that the Polya's learning syntaxmindicator pattern gives brith to the objectives of problem solving learning. Another finding showed that the synthetic indicator of learning patterns gave birth to each cognitive domain in HOTS. HOTS achievment at the elementary school level, especially in the methematics learning procces carried out with an idea planning arrangement, the planning arrangement in question was the Polya learning syntax. Mathematics subject in elementary school require students to have problem solving skills. Based on the result of the study, Polya can make it easier for educatirs ti find out the level of the cognitive level of students, especially in elementary school mathematics.
\end{abstract}

Keywords: Polya, HOTS, mathematics 


\section{PENDAHULUAN}

Sistem pendidikan di Indonesia saat ini sedang menggunakan kurikulum 2013. Tujuan dari implementasi kurikulum 2013 ini adalah membuat peserta didik Indonesia dari jenjang dasar sampai atas lebih aktif dalam proses pembelajaran (student center). Student center sendiri merupakan proses yang memusatkan peserta didik sebagai pusat dari pembelajaran. Pembelajaran di sini merupakan pembelajaran yang mengembangkan potensi peserta didik yang memuat 3 ranah, yaitu kognitif, afektif, dan psikomotor. Salah satu tuntutan dari kurikulum 2013 yaitu peserta didik mempunyai kemampuan berfikir tingkat tinggi (HOTS). Terdapat dua level ranah kognitif menurut taksonomi bloom, yaitu LOTS (Lower Order Thinking Skill) dan HOTS (Higher Order Thinking Skill). Domain kognitif yang termasuk ke dalam LOTS terdiri dari remember, understand, dan apply domain. Pada HOTS, terdiri dari analyze, evaluate, dan create domain. Domain HOTS inilah yang merupakan domain tertinggi dari taksonomi bloom dan peserta didik harus mampu menguasainya.

ACER (Australian Council for Educational Research) menyelenggarakan diskusi yang bertemakan "Mengajar dan Menilai Kemampuan Berpikir Tingkat Tinggi". Diskusi tersebut merupakan bentuk rasa kepedulian terhadap sistem pendidikan di Indonesia setelah melihat hasil peserta didik pada kompetisi ajang PISA (Programme for International Student Assesment) yang dikeluarkan oleh OECD (Organization for Economic Cooperation and Development). Kompetisi ajang PISA tersebut dilakukan sebagai bentuk penilaian sistem pendidikan pada 72 negara melalui tiga kompetensi dasar, yaitu matematika, sains, dan literasi. Indonesia mendapatkan skor sebesar 379 untuk kemampuan matematika, dengan skor ratarata 489 untuk keseluruhan negara yang merupakan anggota dari OECD. Berdasarkan uraian tersebut, perolehan skor Indonesia pada kemampuan matematika masih kurang dari skor rata-rata. Menurut hasil diskusi, penyebab rendahnya penguasaan materi siswa Indonesia dikarenakan proses pembelajaran di sekolah selama ini belum dibiasakan mengerjakan soal-soal menggunakan tipe HOTS.

HOT (Higher Order Thinking) adalah kemampuan berpikir tingkat tinggi yang tidak sekedar hanya mengingat dan menghafal serta menyampaikan informasi yang kita tahu saja, tetapi dapat mengembangkan pengetahuan baru yang lebih 
kritis dan kreatif dalam memutuskan keputusan sebagai upaya menyelesaikan masalah ke dalam kondisi yang baru (Rochmah, 2017). Pernyataan tersebut senada dengan yang dikemukakan oleh Dinni (2018) bahwa HOTS adalah kemampuan untuk mengaitkan dan mengubah informasi yang telah diketahui secara kritis dan kreatif untuk mengambil keputusan dalam memecahkan masalah pada keadan yang baru. HOTS dapat tercapai tidak hanya melalui proses pembelajaran langsung, akan tetapi dibutuhkan komponen pembelajaran lainnya, salah satunya model pembelajaran. Sintaks atau tahapan merupakan bagian dari model pembelajaran, dimana dapat memperlancar proses pembelajaran, baik dari segi pendidik ataupun peserta didik. Polya merupakan salah satu sintaks belajar untuk memecahkan permasalahan matematika. Menurut Juniari et al, (2016) Polya adalah model pembelajaran yang menitikberatkan peserta didik dalam kegiatan berpikir untuk menyelesaikan masalah, khususnya matematika.

Hasil penelitian dari Mustika dan Riastini (2017) yang berjudul "Pengaruh Model Polya Terhadap Kemampuan Pemecahan Masalah Matematika Siswa Kelas V SD" menunjukkan bahwa model pembelajaran Polya berpengaruh terhadap problem solving skill yang dimiliki peserta didik., Hasil penelitian lain dari Ariani dan Kenedi (2018) dengan judul "Model Polya Dalam Peningkatan Hasil Belajar Matematika Pada Pembelajaran Soal Cerita Volume di Sekolah Dasar" menunjukkan meningkatnya presentase hasil belajar peserta didik dari 55\% ke 85\%. Penelitian relevan di atas menarik untuk dikaji tentang hubungan model Polya dengan kemampuan problem solving peserta didik. Hal lain yang menarik penulis melakukan kajian ini adalah kesadaran akan pentingnya kemampuan problem solving dalam pembelajaran matematika. Hakikatnya, problem solving adalah sesuatu integral terhadap pembelajaran matematika, yang berarti bahwa tidak dapat atau bahkan tidak boleh dipisahkan. Problem solving juga merupakan suatu alat dalam memahami matematika itu sendiri selain perannya sebagai tujuan dari pembelajaran matematika. Keberhasilan suatu proses pembelajaran dapat dikarenakan adanya faktor pendukung pembelajaran itu sendiri. Salah satu faktor pendukung dari berhasilnya proses pembelajaran di sekolah yaitu kemampuan ataupun bakat pendidik dalam upaya pencapaian tujuan pendidiikan nasional Indonesia melalui kurikulum 2013. Salah satu upayanya yaitu kemampuan dalam mengkaji hubungan antara sintaks belajar dengan kemampuan yang wajib dimiliki 
peserta didik. Oleh karena itu, peneliti mengkaji hubungan antara sintaks belajar Polya dengan kemampuan pemecahan masalah (HOTS) pada pembelajaran matematika Sekolah Dasar.

\section{METODE PENELITIAN}

Kajian penelitian ini menggunakan jenis penelitian deskriptif kualitatif. Penelitian ini dilakukan dengan mengkaji literatur dan tanpa adanya treatment terhadap suatu objek. Penelitian ini mengambil bidang matematika dikarenakan matematika merupakan salah satu mata pelajaran yang dijadikan dasar untuk mata pelajaran-mata pelajaran lain. Waktu pelaksanaan penelitian ini yaitu selama 3 bulan. Tahapan dari studi literatur yang telah dilakukan yaitu 1) mencari dan mengkaji latar belakang masalah yang akan diteliti, 2) mencari dan mengkaji hasil penelitian yang relevan terkait variabel penelitian, 3) mengumpulkan data dari literatur yang relevan terkait dengan penelitian, 4) melakukan studi literatur berdasarkan hasil data-data yang telah diperoleh, 5) analisis dan sintesis studi literatur, dan 6) penarikan kesimpulan berdasarkan hasil analisis dan sintesis.

\section{HASIL DAN PEMBAHASAN}

\section{Hubungan sintaks Polya dengan aspek HOTS}

Sistem pendidikan yang saat ini memakai kurikulum 2013 di satuan pendidikan mewajibkan memasukkan HOTS dalam kegiatan belajar mengajar. Tujuan dari adanya pembelajaran berbasis HOTS adalah tidak lain untuk meningkatkan daya pikir peserta didik serta mampu menyelesaikan permasalahan-permasalahan yang ada. Berdasarkan hasil diskusi yang diselenggarakan oleh ACER, proses pembelajaran siswa Indonesia di sekolah selama ini belum dibiasakan mengerjakan soal-soal menggunakan tipe HOTS, sehingga penguasaan materi pada mata pelajaran matematika tergolong rendah. Salah satu upaya dalam meningkatkan kemampuan berpikir tingkat tinggi (HOTS) adalah menerapkannya suatu model pembelajaran. Model pembelajaran merupakan rangkaian kegiatan pembelajaran yang terbentuk secara sistematik. Biasanya, seorang guru atau pendidik akan mengembangkan langkah kegiatan dari suatu model pembelajaran yang digunakan. Terdapat banyak model pembelajaran yang mendukung di sistem kurikulum 2013 saat ini, salah satunya 
adalah sintaks belajar Polya. Polya merupakan sintaks belajar yang memberikan langkah-langkah secara runtut dalam memecahkan masalah matematika. Sintaks belajar dari Polya sendiri yaitu (1) memahami suatu permasalahan matematika, kemudian (2) merencanakan sebuah penyelesaian masalah matematika, dilanjutkan (3) menjalankan penyelesaian masalah matematika yang telah dirancang, kemudian diakhiri dengan (4) menguji kembali solusi yang digunakan (Noviantari, 2018).

Sintaks belajar pertama Polya yaitu memahami masalah. Tahapan ini menuntut peserta didik untuk lebih terampil dalam memilih data informasi yang sesuai. Sintaks ke-2 dan ke-3 adalah menyusun rencana dan melaksanakan rencana. Tahapan ini menuntut peserta didik untuk dapat menganalisis hasil data informasi yang telah dipilih dan ditentukan sebelumnya sehingga mendapatkan rencana yang harus dilaksanakan untuk memecahkan masalah. Kemudian peserta didik diminta untuk melakukan hasil rencana tersebut. Sintaks ke-4 adalah menguji kembali hasil yang didapat. Pada tahap ini peserta didik diminta untuk meneliti kembali hasil yang didapatkan untuk mengetahui kebenaran dan kekurangannya dan memperbaikinya.

Salah satu aspek dari keterampilan berpikir tingkat tinggi (HOTS) adalah kemampuan pemecahan masalah atau problem solving. Idealnya, suatu kegiatan pembelajaran tidak sekedar terfokus pada perlombaan guna memperoleh nilai setinggi-tingginya pada peserta didik. Namun, suatu aktivitas pembelajaran harus juga memberikan pengetahuan tentang cara bagaimana memecahkan masalah-masalah khusus ke dalam situasi baru yang ada kaitannya dengan materi yang dipelajari saat itu. Maka dari itu, problem solving sering didefinisikan sebagai proses kegiatan dimana setiap individual mampu menggunakan konsep pengetahuannya untuk menciptakan sesuatu ke dalam kondisi baru. Pembelajaran seperti yang telah disampaikan tak lain bertujuan melatih kemampuan peserta didik untuk menjadi lebih kritis dan kreatif dalam menerima informasi sesuai yang nantinya akan dikaji kebutuhannya, dan menguji kembali hasilnya. Berdasarkan makna tersebut, bahwa sintaks belajar Polya menunjukkan keselarasan dengan tujuan pembelajaran pemecahan masalah atau problem solving pada mata pelajaran matematika. Berikut bagan hubungan ditunjukkan pada Gambar 1. 


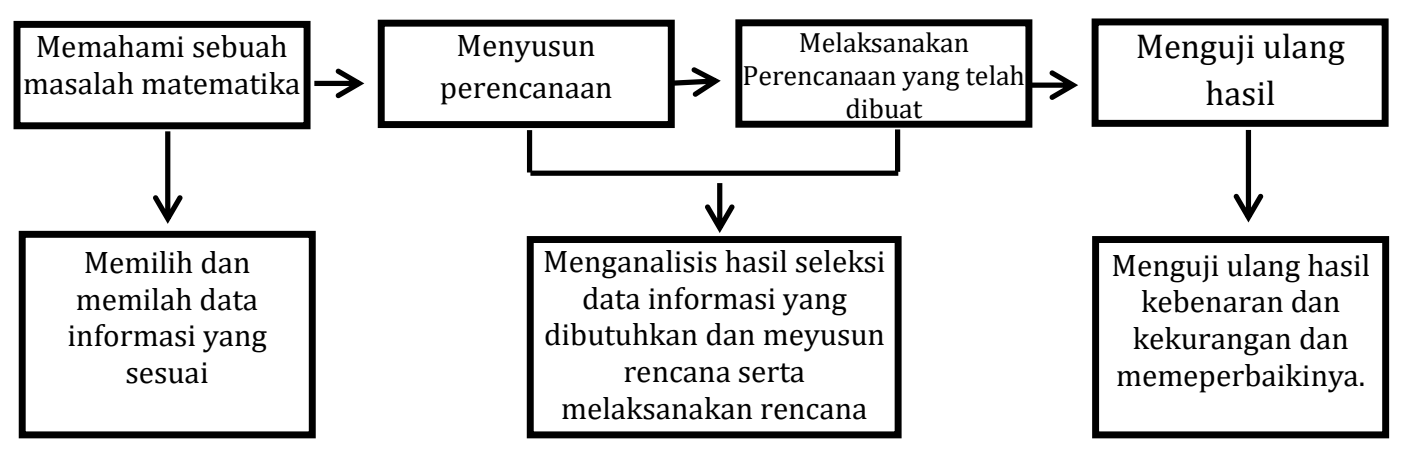

\section{Gambar 1. Hubungan Polya dengan tujuan Problem Solving}

\section{Hubungan sintaks Polya dengan domain HOTS}

Penelitian yang bertujuan untuk melatih kemampuan HOTS peserta didik melalui model pembelajaran Polya telah banyak dilakukan. Meninjau sintaks belajar Polya, Ariani dan Kenedi (2018) mengemukakan bahwa implementasi model pembelajaran Polya dapat membantu peserta didik dalam mendapatkan pengalaman dan pengetahuan baru melalui pengalaman dan pengetahuan yang telah dimiliki peserta didik lebih awal, yang kemudian nantinya akan diterapkan guna menyelesaikan suatu permasalahan yang sifatnya tidak rutin. Hal tersebut juga dapat merangsang proses berpikir peserta didik. Penelitian yang dilakukan oleh Ernawati dan Sutiarso (2020) juga memberikan informasi bahwa dalam meninjau kesulitan mengerjakan matematika tipe HOTS dapat ditinjau melalui sintaks Polya. Gambar 1 menunjukkan bahwa tujuan dari pembelajaran problem solving untuk meningkatkan HOTS dapat dicapai dengan sintaks belajar Polya. Seperti hasil penelitian yang telah dijabarkan sebelumnya, bahwa sintaks belajar Polya memiliki pengaruh terhadap kemampuan problem solving yang dimiliki peserta didik. Kemudian, persentase hasil belajar peserta didik dapat meningkat setelah menggunakan sintaks belajar Polya. Hasil penelitian tersebut dapat dimaknai bahwa sintaks belajar Polya merupakan tahapan yang dapat mempengaruhi kemampuan pemecahan masalah matematika peserta didik dan dapat meningkatkan hasil belajar peserta didik. Berdasarkan hal tersebut, terdapat indikator yang menyebabkan pencapaian keberhasilan. Berikut adalah indikator pencapaian ranah kognitif pada HOTS ditunjukkan pada tabel 1. 
Tabel 1. Indikator Pencapaian Ranah Kognitif pada HOTS

\begin{tabular}{|c|c|}
\hline $\begin{array}{c}\text { Ranah } \\
\text { Kognitif }\end{array}$ & Indikator \\
\hline \multirow{3}{*}{$\begin{array}{c}\text { C4 } \\
\text { Menganalisis }\end{array}$} & $\begin{array}{l}\text { Menganalisis setiap data informasi yang ada dan memilih } \\
\text { serta memilah atau menyusun data informasi tersebut } \\
\text { melalui model kalimat matematika yang memiliki } \\
\text { keterkaitan. }\end{array}$ \\
\hline & $\begin{array}{l}\text { Dapat mengetahui dan membedakan unsur yang menjadi } \\
\text { penyebab dan akibat suatu permasalahan yang ada. }\end{array}$ \\
\hline & Menyusun rumusan suatu kalimat pertanyaan. \\
\hline \multirow{3}{*}{$\begin{array}{c}\text { C5 } \\
\text { Mengevaluasi }\end{array}$} & $\begin{array}{l}\text { Melakukan penilaian untuk memberikan solusi dengan } \\
\text { strandar kriteria yang sesuai. }\end{array}$ \\
\hline & $\begin{array}{l}\text { Melakukan sebuah kritikan, menyusun prediksi jawaban } \\
\text { sementara, dan melakukan pengujian terhadap kebenaran. }\end{array}$ \\
\hline & $\begin{array}{l}\text { Dapat menolak atau menerima terhadap sebuah pernyataan } \\
\text { dan didasarkan oleh kriteria yang sudah ditetapkan. }\end{array}$ \\
\hline \multirow{3}{*}{$\begin{array}{c}\text { C6 } \\
\text { Mencipta }\end{array}$} & $\begin{array}{l}\text { Dapat menyusun suatu kesimpulan dari ide atau cara } \\
\text { pandang pada suatu objek. }\end{array}$ \\
\hline & $\begin{array}{l}\text { Menyusun sebuah cara untuk menyelesaikan suatu } \\
\text { permasalahan. }\end{array}$ \\
\hline & $\begin{array}{l}\text { Membuat suatu komponen-komponen atau bagian-bagian } \\
\text { yang belum pernah ada sebelumnya menjadi struktur baru. }\end{array}$ \\
\hline
\end{tabular}

Mengingat domain ranah kognitif pada HOTS terdiri dari analisis, evalausi, dan mencipta, oleh karena itu level ranah kognitif dapat diaplikasikan pada kelas tinggi (IV-VI). Pada kriteria tersebut, memerlukan indikator untuk mengukur ketercapaiannya. Indikator dalam pencapaian kemampuan High Order Thinking Skill di atas dikemukakan oleh Krathworl (Suryapuspitarini et al, 2018). Kesesuaian indikator pencapaian kemampuan HOTS dapat ditinjau dari definisi setiap domain-domain HOTS yang dimulai dari C4 sampai dengan C6. Definisi domain kemampuan HOTS membantu dalam menilai apakah indikator pencapain HOTS sudahkah sesuai, cocok, atau bahkan sinkron. 
Tabel 2. Definisi Ranah Kognitif HOTS

\begin{tabular}{cl}
\hline Ranah & \multicolumn{1}{c}{ Definisi } \\
Kognitif & Mencari data informasi sedalam dan sebanyak-banyaknya \\
\hline C4 & supaya dapat memahami semua hal yang dibutuhkan. \\
Menganalisis & $\begin{array}{l}\text { Melakukan kritikan dan masukan serta penilaian sesuai } \\
\text { C5 }\end{array}$ \\
Mengevaluasi & dengan kriteria yang ditentukan. \\
C6 & Membuat ide dan gagasan baru berdasarkan apa yang telah \\
Mencipta & $\begin{array}{l}\text { dipahami sebelumnya sesuai dengan kriteria yang telah } \\
\text { ditetapkan. }\end{array}$ \\
\hline
\end{tabular}

Tabel 2 di atas dijelaskan bahwa setiap ranah kognitif pada taksonomi bloom pata level C4, C5, dan C6 memiliki definisi mencari informasi, melakukan penilaian, membuat ide baru. Definisi tersebut selaras dengan sintaks belajar Polya, yaitu tahap pertama dalam memahami masalah sama halnya dengan mencari dan menganalisis data. Tahap kedua dan ketiga dalam menyusun serta menjalankan perencanaan masalah sama halnya dengan membuat ide atau gagasan baru. Tahap keempat dalam menguji kembali hasil sama halnya dengan mengevaluasi hasil atau temuan yang diperoleh. Hal lain yang dapat membantu untuk melihat hubungan model pembelajaran Polya dengan HOTS yaitu menganalisis kecocokan yang terdapat dalam indikator HOTS dengan indikator sintaks belajar Polya. Analisis dilakukan dengan memahami makna yang terkandung. Persamaan makna yang ditemui menunjukkan adanya hubungan antara model pembelajaran Polya dengan HOTS.

\section{C4 / Menganalisis}

Kriteria menganalisis dapat mencapai tujuan dari sintaks belajar Polya yang pertama, yaitu memahami masalah. Pada kriteria menganalisis ini, indikator yang digunakan antara lain mengidentifikasi semua informasi yang ada dalam suatu masalah yang diberikan, menuliskan kalimat pertanyaan berdasarkan kondisi suatu permasalahan, serta memeriksa kembali semuan informasi yang diberikan sudahkah cukup untuk menjawab suatu pertanyaan.

Indikator pencapaian di atas merupakan sebuah cara yang dilakukan untuk mengetahui sedalam-dalamnya informasi yang dibutuhkan. Hal ini menunjukkan bahwa sintaks belajar Polya dapat dicapai dari definisi domain 
menganalis, yaitu "menggali informasi sedalam-dalamnya, sehingga paham betul tentang apa yang dibutuhkan".

\section{C5 / Mengevaluasi}

Kriteria mengevaluasi dapat mencapai tujuan dari sintak belajar Polya yang terakhir. Ketercapaian dapat terwujud melalui indikator melakukan pemeriksaan kembali terhadap hasil yang telah diperoleh berdasarkan peryataan yang diberikan dan memerikan dan mencari jawaban lain jika ditemukan.

Indikator pencapaian di atas merupakan berbagai cara yang dilakukan untuk looking back atas perencanaan yang telah disusun. Hal ini menunjukkan bahwa sintaks belajar Polya dapat dicapai dari definisi domain mengevaluasi, yaitu "memberikan sebuah kritikan serta penilaian tentang apa yang telah menjadi kriteria ketetapan".

\section{C6 / Mencipta}

Kriteria mencipta dapat mencapai tujuan dari sintaks belajar Polya yang kedua. Tahapan kedua model Polya yaitu menyusun dan melaksanakan rencana untuk memecahkan masalah. Merencanakan dan melaksanakan penyelesaian masalah merupakan kegiatan menciptakan sebuah solusi yang akan digunakan untuk memecahkan permasalahan nantinya. Hal ini menunjukkan bahwa sintaks belajar Polya dapat dicapai dari definisi domain mencipta, yaitu "melakukan sebuah ide baru tentang apa yang telah dipahami dan didasarkan oleh kriteria ketetapan".

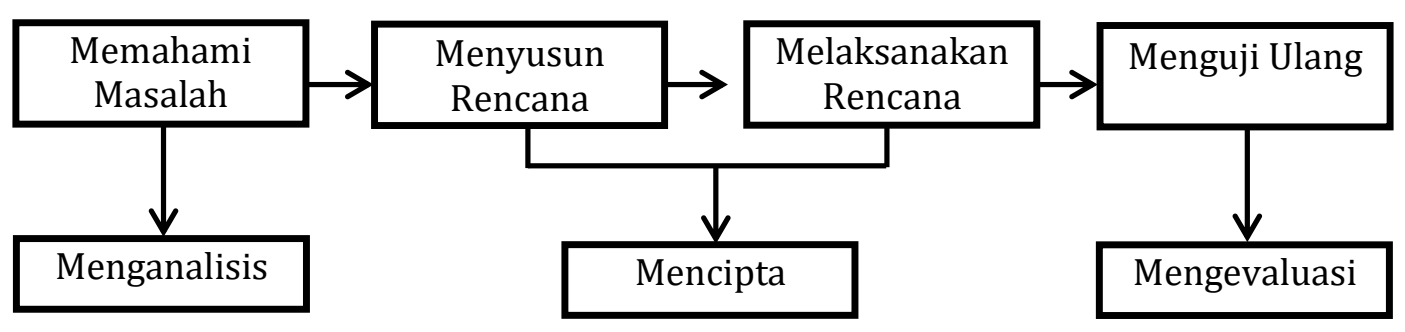

Gambar 2. Hubungan HOTS dan Sintaks Belajar Polya 
Berikut ini indikator pemecahan masalah dari sintaks belajar Polya yang dirumuskan oleh Puspa et al (2019: 88) dan dapat dilihat pada tabel 3 di bawah ini.

Tabel 3. Indikator Pemecahan Masalah Bedasarkan Polya

\begin{tabular}{|c|c|}
\hline Langkah & \\
\hline \multirow{3}{*}{$\begin{array}{l}\text { Memahami } \\
\text { Masalah }\end{array}$} & $\begin{array}{l}\text { Dapat mengidentifikasi informasi yang sesuai dengan } \\
\text { permasalahan yang disajikan. }\end{array}$ \\
\hline & $\begin{array}{l}\text { Dapat menyusun kalimat pertanyaan sesuai permasalahan yang } \\
\text { disajikan. }\end{array}$ \\
\hline & $\begin{array}{l}\text { Dapat melakukan pemeriksaan informasi yang diberikan untuk } \\
\text { mengatehaui kekurangan informasi. }\end{array}$ \\
\hline \multirow{3}{*}{$\begin{array}{c}\text { Merencanakan } \\
\text { Penyelesaian } \\
\text { Masalah }\end{array}$} & $\begin{array}{l}\text { Dapat membuat hubungan antara informasi yang diperoleh } \\
\text { dengan kalimat pernyataan. }\end{array}$ \\
\hline & $\begin{array}{l}\text { Dapat menyusun model matematika untuk memecahkan } \\
\text { masalah matematika. }\end{array}$ \\
\hline & $\begin{array}{l}\text { Dapat menunjukkan rancangan yang akan dilakukan untuk } \\
\text { memecahkan masalah. }\end{array}$ \\
\hline \multirow{2}{*}{$\begin{array}{c}\text { Melaksanakan } \\
\text { Penyelesaian } \\
\text { Masalah }\end{array}$} & $\begin{array}{l}\text { Dapat memeriksan dan melaksanakan setiap langkah } \\
\text { penyelesaian sesuai dengan rancangan yang telah dibuat. }\end{array}$ \\
\hline & $\begin{array}{l}\text { Dapat melakukan pemeriksaan kembali setiap langkah yang } \\
\text { telah dilakuan. }\end{array}$ \\
\hline \multirow{3}{*}{$\begin{array}{l}\text { Melihat } \\
\text { Kembali }\end{array}$} & $\begin{array}{l}\text { apat memeriksa hasil jawaban berdasarkan pertanyaan yang } \\
\text { iberikan. }\end{array}$ \\
\hline & $\begin{array}{l}\text { Dapat melalukan pemeriksaan pendapat terkait hasil yang } \\
\text { diperoleh. }\end{array}$ \\
\hline & $\begin{array}{l}\text { Dapat melakukan pemeriksaan atau menemukan jawaban lain } \\
\text { yang mungkin diperoleh. }\end{array}$ \\
\hline
\end{tabular}

Berdasarkan tabel 3 di atas, sintaks belajar Polya merupakan tahapan yang harus dilakukan secara bertahap dan tidak dianjurkan secara acak. Hal ini peran sintaks Polya sejalan dengan karakteristik pembelajaran matematika sekolah dasar.

\section{Pembelajaran matematika sekolah dasar}

Pembelajaran matematika bertahap merupakan salah satu karakteristik pembelajaran matematika di jenjang Sekolah Dasar. Pembelajaran matematika di jenjang Sekolah Dasar tidak hanya dimulai dari sesuatu yang bersifat konkret, semi konkret, dan abstrak, namun juga perlu dimulai dari konsep-konsep yang paling sederhana menuju konsep yang lebih sulit tingkatannya. Karakteristik 
peserta didik yang berbeda-beda dalam penguasaan materi terutama pada mata pelajaran matematika, maka untuk mencapai penguasaan konsep pasti membutuhkan proses. Sejalan dengan hal tersebut, Kemendikbud menyampaikan bahwa mata pelajaran matematika pada jenjang Sekolah Dasar untuk kelas tinggi (IV-VI) harus dipisah dari pembelajaran tematik. Hal ini dikarenakan muatan karakter pada mata pelajaran matematika berbeda dari muatan mata pelajaran lain. Matematika juga merupakan ilmu universal yang dijadikan sebagai disilpin ilmu yang digunakan oleh semua bidang ilmu lainnya. Misalnya bidang farmasi, geografi, kedokteran, sains, dan lain sebagainya. Maka dari itu pada jenjang Sekolah Dasar, matematika pada kelas tinggi tidak dimasukkan ke tema-tema dikarenakan memang matematika kelas tinggi menuntut peserta didik untuk lebih fokus menguasai konsep matematika. Selain itu, juga tidak mudah untuk mengintegrasikan semua materi matematika ke dalam tema-tema yang ada pada kurikulum 2013.

Mata pelajaran matematika memang membutuhkan kecakapan berpikir dalam proses pembelajarannya. Kecakapan berpikir ini sering disebut sebagai kecakapan 4C yang kemampuannya meliputi berpikir kritis, berpikir kreatif, kolaboratif, dan komunikatif dalam menguasai suatu konsep matematika yang tergolong abstrak. Kritis dalam memahami konsep, kreatif dalam menciptakan sebuah gagasan ataupun ide, berkolaborasi dalam menyelesaikan permasalahan, dan mengkomunikasikan hasil penyelesaian pembelajaran. Sejalan terkait ini, alasan dibelajarkannya mata pelajaran matematika di jenjang Sekolah Dasar yaitu guna membekali peserta didik untuk menguasai berbagai kemampuan, antara lain (1) berpikir logis, (2) berpikir analitis, (3) berpikir sistematis, (4) berpikir kritis dan kreatif, serta (5) bekerja sama. Mata pelajaran Matematika juga dinilai sebagai bidang yang membutuhkan penguasaan pendalaman materi yang khusus dibandingkan dengan muatan mata pelajaran lain di jenjang Sekolah Dasar (Setiawan 2020). Kemampuan berpikir pada pembelajaran matematika di Sekolah Dasar tersebut guna mencapai tujuan dari pembelajaran matematika yang digagas oleh Permendiknas yang salah satunya yaitu memecahkan suatu kasus permasalahan. Kemampuan yang dikembangkan dalam hal ini meliputi kemampuan (1) memahami permasalahan, (2) merancang model matematika, (3) menyelesaikan dan menjalankan model matematika, dan (4) dalam 
menafsirkan solusi yang diperoleh (Batubara, 2017). Berdasarkan hal tersebut, maka karakteristik pembelajaran matematika di jenjang usia Sekolah Dasar terutama di kelas tinggi yaitu 1) sesuai dengan indikator-indikator yang ada pada HOTS yaitu menganalisis, mengevaluasi, dan mencipta, 2) tahap perkembangan kognitif peserta didik usia Sekolah Dasar pada kelas tinggi sudah mampu berpikir pada tingkat semi abstrak dan abstrak, 3) materi pembelajaran matematika bersifat bertahap sehingga tidak dapat memberikan pengetahuan yang berhubungan dengan matematika sesuai keinginan pendidik.

\section{SIMPULAN}

Pada hakekatnya, tingkatan berpikir terbagi menjadi tiga kemampuan, yang terdiri dari LOST, MOST, dan HOTS. Akan tetapi, tidak sedikit yang menganggap bahwa keberadaan MOST ini tidak ada. Menurut peneliti sendiri, tahap MOST ini merupakan sebuah peralihan kemampuan tingkat berpikir individu. Akan tetapi, bukan berarti tingkat berpikir pada tahap LOTS dan MOST tidak penting. Justru keduanya merupakan tahap dalam mencapai kemampuan HOTS. Hal inilah yang sering terjadi kekeliruan di seputar dunia pendidikan. Harapannya, seorang pendidik harus membiasakan sebuah tahapan perencanaan ide dalam mencapai kemampuan berpikir tingkat tinggi, seperti menyuguhkan kata kerja operasional yang ada dalam taksonomi bloom dan menerapkan model pembelajaran.

Berdasarkan hasil studi literatur yang telah diuraikan di atas, maka dapat disimpulkan bahwa 1) sintaks belajar Polya mempunyai hubungan erat dengan HOTS baik dari segi aspek HOTS, yang ditunjukkan dengan adanya keterkaitan dengan langkah-langkah sintaks belajar Polya dengan aspek problem solving, 2) sintaks belajar Polya mempunyai hubungan dengan ranah kognitif HOTS, yang ditunjukkan dengan sesusuaian makna dari indikator-indikator sintaks belajar Polya dan ranah kognitif HOTS, 3) karakteristik pembelajaran matematika di jenjang usia Sekolah Dasar selaras dengan sintaks belajar Polya yang bertahap sesuai dengan perkembangan kognitif peserta didik di jenjang usia Sekolah Dasar. Maka dari itu, melalui sintaks belajar Polya, dapat mempermudah pendidik untuk mengetahui tingkatan level ranah kognitif peserta didik. Keberhasilan suatu proses pembelajaran dapat dicapai dengan kompetensi atau kemampuan pendidik yang mengetahui adanya hubungan antara sintaks belajar dengan karakteristik peserta 
didik. Oleh karena itu, adanya hasil studi literatur ini dapat dijadikan bahan informasi tambahan supaya para pendidik dapat mengolah pengetahuan sesuai dengan yang teori yang telah ada.

\section{DAFTAR PUSTAKA}

Ariani, Y., \& Kenedi, A. K. (2018). Model Polya dalam peningkatan hasil belajar matematika pada pembelajaran soal cerita volume di sekolah dasar. Jurnal Inspirasi Pendidikan, 8(2), 25-36.

Batubara, H. H. (2018). Pengembangan media pembelajaran Matematika berbasis android untuk siswa SD/MI. Jurnal Madrasah Ibtidaiyah, 3(1), 12-27.

Dinni, H. N. (2018). HOTS (High Order Thinking Skills) dan kaitannya dengan kemampuan literasi Matematika. Prosiding Seminar Nasional Matematika, 1, 170-176.

Ernawati, \& Sutiarso, S. (2020). Analisis kesulitan menyelesaikan soal Matematika kategori Higher Order Thinking Skills menurut tahapan Polya. Jurnal Penelitian Pembelajaran Matematika, 13(2), 178-195.

Juniari, L. S., et al. (2016). Pengaruh model pembelajaran Polya berbantuan media By Design terhadap hasil belajar Matematika siswa kelas V SD. Mimbar PGSD Undiksha, 4(1).

Mustika, I. K. A., \& Riastini, P. N. (2017). Pengaruh model Polya terhadap kemampuan pemecahan masalah matematika siswa kelas V SD. International Journal of Community Service Learning, 1(1), 31-38.

Noviantari, P. S. (2018). Penerapan model Polya berorientasi masalah soal cerita kontekstual untuk meningkatkan kemampuan pemecahan masalah matematika siswa kelas V SD Negeri 7 Bugbug. Jurnal Santiaji Pendidikan (JSP), 8(1), 19-27.

Puspa, R. D., et al. (2019). Analisis kemampuan siswa dalam menyelesaikan soal tipe Higher Order Thinking Skills (HOTS) ditinjau dari tahapan pemecahan masalah Polya. Jurnal Kajian Pembelajaran Matematika, 3(2), 86-94.

Rochmah, N. W. (2017). Analisis kemampuan siswa dalam pemecahan masalah berpikir tingkat tinggi atau HOT (Higher Order Thinking) bedasarkan langkah Polya (Disertasi, Pendidikan Matematika-FKIP).

Setiawan, Y. (2020). Pengembangan model pembelajaran Matematika SD berbasis permainan tradisional Indonesia dan pendekatan Mmatematika realistik. Jurnal Pendidikan dan Kebudayaan, 10(1), 12-21. 
Suryapuspitarini, B.K., et al. (2018). Analisis soal-soal Matematika Tipe Higher Order Thinking Skill (HOTS) pada kurikulum 2013 untuk mendukung kemampuan literasi siswa. Prosiding Seminar Nasional Matematika, 1, 876-884. 